\title{
Beyond the Brink
}

\section{Indigenous Women's Agency and the Colonisation of Knowledge in the Maid of the Mist Myth}

\section{ROBINDER KaUR SEHDEV}

INDEPENDENT SCHOLAR

The story of the Maid of the Mist is central to Niagara Falls as a historical space of tourist exchange and settler colonialism. Given its importance, it seems paradoxical that the story is now shunned, relegated to the peripheries of settler consciousness. Where in the past the story of the 'Indian maiden' poised at the brink of Niagara Falls adorned local popular culture, today it exists in the form of that more general moniker, 'the Maid of the Mist' which the steamboat corporation has appropriated. Attention to the story itself is now all but drained away. Why was this myth rendered marginal and what does its marginality mean in a context of settler power and privilege? In this article I argue that the Maid of the Mist myth attempts to displace Indigenous knowledge systems and silence the agency of Indigenous women. The Maid of the Mist myth cannot be dismissed as a quirky flourish or romantic story solely designed to draw crowds to the waterfalls; it was central to the colonial imperative to displace Indigenous knowledge through the diminished representation of the 'Indian maiden'. In other words, the Maid of the Mist myth is not a tourist myth but a settler one and I argue that its dismissal today is a further continuation of the colonial imperative, under the guise of correcting racist wrongs. Settlerhood is contingent on the conditional vanishing of Native womanhood, a representational practice inextricably woven into the political field. 
-THE MAID

Sherene Razack defines a settler society as one 'established by Europeans on nonEuropean soil'.1 The place of the settler is secured through the establishment and reproduction of racial hierarchies, which position European settlers and their descendants as the rightful inheritors of the 'New World'. Razack notes that settler societies are created and maintained through dispossession and genocide that can never be acknowledged as violence. Settler myths are vital here, as they offer a means of disavowing the systemic and systematic acts of violence against Indigenous people and people of colour in the making of the settler state. ${ }^{2}$ These myths also offer stories of shared origins and belonging on the land and in the nation. 'Settler culture' refers to the lived experience, representations and discourses of colonists who have made a home in Indigenous spaces. More than simply a matter of transoceanic movement, settlerhood is contingent on the assumption of its indisputable right to be and its absolute denial of the normativity of Indigenous nations which preexisted contact and continue to survive and innovate within and beyond the settler state. Settler culture is not settled culture: in its day-to-day operation, internal contradictions within settler culture unwittingly reveal the always-incomplete process of normalisation. The settler's home is based on a number of myths: myths of total conquest, which disregard Indigenous resistance and cultural life beyond colonisation; myths of exclusive ownership of the land along with the Eurocentric presumptions of what the land means and how best to use it; and myths of innate superiority where the language of race is operationalised to justify colonial violence. Settler stories of Aboriginal peoples and intercultural contact reveal more about how racism and sexism are woven together to produce the fabric of such stories than they do about contact or the lives, cultures and societies of Indigenous people. ${ }^{3}$ The Maid of the Mist is such a story.

While there are variations, the Maid of the Mist myth is essentially the story of an Indigenous woman's culturally required suicide at the waterfalls. By piloting her canoe over the brink, she becomes a blood offering to the angry river god. This god, who is always represented as male, makes the maid his bride. She seldom takes the plunge alone; often her father or her male lover break from the crowd on shore and sprint their canoes to join her before both drop into the mist. This is not an Indigenous story; it is rooted in settler fantasies of Indigenous sexuality, like many 
other stories of 'Indian maidens'. Terry Goldie identifies the operation of race within settler representational forms by calling out the 'white text' which is secured as 'white space' through the containment of race and sex in a single salient image: the 'Indian maiden'. ${ }^{4}$ This image enables otherwise inexpressible colonial sexual-racial anxieties and it is therefore critical to the settler's morally superior (that is, 'normally' sexual or heteronormative and 'purely' white) self-representation. In other words, the settler's sexuality and fear of racial 'contamination' are repressed and emerge in the image of the Indigenous maiden as the bearer of literally dark, and tantalisingly dangerous sexuality that is inevitably met with racialised and sexualised violence. ${ }^{5}$ This is why, as M. Elise Marubbio argues, the 'Indian maiden' of the silver screen inevitably dies. ${ }^{6}$ Settler culture's 'Indian maiden' merges the image of the Indigenous woman with the landscape, thus making her the symbolic frontier envisioned as both 'savage' and sexual.7 In this symbolic merging of the land and woman's body, the assumed 'right' to conquer both is intertwined and violently enacted.

Karen Dubinsky supposes that the oral version of the Maid of the Mist story can be traced as far back as 1753, to an anonymous fur trader's yarn of a Haudenosaunee (or Iroquois) man who loses control of his canoe and is carried over the falls. ${ }^{8}$ To be sure, there were many such stories of Haudenosaunee men losing control of their canoes before the cataract, falling from precarious staircases, ladders or bridge-like structures at Goat Island or the gorge, or drowning in the river's whirlpools. Such stories are thinly veiled attacks on Indigenous belonging in Indigenous spaces. These, in turn, were endorsements of settler belonging and superiority. The attendant assumptions were that Indigenous men (because women, especially Indigenous women, were not recognised as carriers and innovators of technological and ecological knowledges) lacked the intelligence and ability to inhabit and control their lands and waters. The notion of the land and water as things to control, and expressly of Indigenous men's failure to control even the trajectory of their own bodies on the land- and waterscape, hints as the operation of colonial sexual anxiety.

If the roots of the Maid of the Mist story can be traced to yarns about Indigenous men, the conspicuous masculinity of those unfortunate and fatally incompetent men is worth some attention in comparison to the maid's obvious 
femininity and her suicidal trajectory. Anne McClintock writes of imperialism as the site of profound sexual anxieties, as much as it is the amalgam of discourses, perceptions and practices of domination. ${ }^{9}$ Imperial Europe's creation and subsequent fixation upon the 'monstrous sexuality' of its Other ensures that stories like the Maid of the Mist were not just possible, they were inevitable. Contained in settler myths, these representations of Indigenous sexuality gone awry offer a narrative of a doomed people in desperate need of colonial 'guidance'.10 The young, beautiful Indigenous woman, embodying primitive sexuality strong enough to satiate a temperamental god finds its roots in the image of Indigenous men's incompetence. While the maid's journeying over the falls is intentional, these men are simply swept over against their wills. The dominant masculine figures of the story play oddly against the maid's utilitarian femininity: the god is an altogether unseen but always explicitly masculine force, while the maid's sullen father or impetuous lover are unable to alter the fate of the maid and must submit to the river's current. Theirs is a conspicuously failed masculinity as per the settler's race-gender schema.

While settler stories may attempt to smooth over the realities of colonial violence, they fundamentally settle nothing. Beth Brant (citizen of the Haudenosaunee Confederacy) turns to the myth of Pocohontas in settler history, arguing that it attempts to displace the actual historical woman. ${ }^{11}$ Brant retrieves Pocohontas from the realm of settler myths by deconstructing the representation and reconstructing Indigenous women's history. Rather than surrendering to the popular cultural practice of reducing Indigenous women, so vital to the political, spiritual and cultural lives of their nations, to 'Indian maidens', Brant suggests that 'somewhere outside their legends the real truth lies'.12 Beginning from popular myths of Pocohontas as 'a good christian [sic]' and 'good capitalist' who 'enthusiastically fell in love' with British colonist John Smith, Brant offers an alternate narrative of Pocohontas's life. She presents it as a way of envisioning the life stories of women beyond the seemingly totalising image of the maid by recentering Indigenous women as diplomats and political leaders interested in cementing good relations with neighboring nations. This was certainly the case with Pocohontas' community, and as daughter of Chief Wahunsonacock of the Algonquin Confederacy she would have been trained and ready to fill this role. 'The continuation of the Indian people was uppermost in the daughter's and father's 
minds ... Pocahontas saw the alternative to genocide as adopting John Smith as her brother.'13 Brant reads Pocohontas as an agent who successfully navigated dangerously changing currents of power (thanks to colonial interference in Indigenous political systems and trade networks) and broke a path for subsequent generations of Indigenous people born into a settler colonial world. She was neither comprador nor victim.

Settler cultural representational practices of employing intermittent visibility and invisibility affects Indigenous women at Niagara Falls just as it defines the Pocohontas and Maid of the Mist myths. As part of the North American Grand Tour, or travel circuit for bourgeois Europeans and Americans, Niagara Falls relied heavily on Tuscarora women to produce beadwork souvenirs, which in the early to mid 1880s functioned as the tourist's certificate of authenticity, proof they had made the trek to the famous cataract. Fueled by the colonial notion that Indigenous peoples were on the brink of disappearing, the beadwork also served as a curiosity or artefact, the tourist could own something that was surely the last of its kind. The tourists who so eagerly bought beadwork from Tuscarora women were not innocent of the colonial exchange. Jolene Rickard reflects on the practice: 'The money put down on the table is merely a token. What is really being purchased is a monetary release from the crimes of the past.'14 In the minds of the tourists, the women who produced the beadwork were spectralised bodies, whose only impact on the physical world was affected through bead and cloth.

Tuscarora women's labour and the tourist dollar figured significantly in the 1830s when the government of the United States of America declared it would deport the Tuscarora from their lands in the Niagara region to Oklahoma unless they could demonstrate economic self-sustainment. ${ }^{15} \mathrm{~A}$ rich prospector named Augustus Porter bought Goat Island, the island dividing the American and Canadian falls, charged tourists admission to enter and permitted Tuscarora women to sell their beadwork there. ${ }^{16}$ If not for the sagacious productivity of Tuscarora women, Porter's capital and the tourist impulse to authenticity, the Tuscarora Nation would likely have faced a second dispossession. ${ }^{17}$ This 'inevitably lopsided cultural exchange' should not diminish the significance of the beadwork and the intellectual, cultural and skilled manual work that went into its production. ${ }^{18}$ Jolene Rickard positions the beadwork and the women who created it as 'messengers' who communicate a 
faithful adherence to their nation's sovereignty as well as 'a reminder of our [Indigenous] spiritual, economic and cultural survival' in spite of the grossly unequal conditions of cultural consumption and continued colonisation. This beadwork was no salute to a vanishing culture. Likewise, it was no submission to the increasing commercialisation of Niagara Falls. The beadwork communicates the cultural vitality and principles of the Ska ru re (also known as the Tuscarora Nation of the Haudenosaunee Confederacy) in the face of settler colonial power. After all, as Rickard notes, 'It takes time to put thousands of tiny beads on cloth; it teaches you the patience to observe, the ability to see things as a whole or a multitude of parts. It is important to see how things are connected and what gives them life.' According to Rickard, non-Indigenous tourists regard the beadwork as 'whimsies' for the tourist economy, thus failing to recognise Indigenous women's decolonial agency as they directed their labour toward sovereignty and cultural survival. ${ }^{19}$

While Niagara's Maid of the Mist has no root in an actual woman, which the Pocohontas myth does, it can similarly be read as a site of resistance and a deeply problematic, uneasy marker of Indigeneity in a place that is often and too quickly trivialised and commodified. This is both a powerful and tricky proposition: on one hand, the settler myth of the Maid of the Mist tells a story of a Native woman's death in keeping with the colonial 'Indian maiden' trope. On the other hand, it affirms Indigeniety as central to the space by returning the eye to the feminine, the Indigenous and the sacred. It is evocative of Mature Flowers (the Tuscarora nation's name for the woman who falls from the Sky World and with the help of the water and animal worlds, gives birth to the land's first people). This is a powerful reminder that Niagara Falls is a sacred place of meeting and meaning, governed by the principle of good relations grounded in Indigenous diplomatic practices, rules of governance and philosophies of the sacred. Attempting to efface the Maid of the Mist from Niagara's cultural landscape obscures the representational and material violence done against Indigenous community and sovereignty through the colonial diminishment of Indigenous women and the attempted imposition of colonial knowledge systems. 
-THE MYTH

While the story existed earlier in local folklore, the first literary appearance of the Maid of the Mist is found in Andrew Burke's 'Descriptive Guide; Or, the Visitors' Companion to Niagara Falls: Its Strange and Wonderful Localities' (1851). ${ }^{20}$ At first glance, the Maid of the Mist appears out of place at the very end of the chapter 'Accidents which have occurred at the Falls,' which is dedicated to deaths by accident and suicide at Niagara. Of the six morbid stories, four involve people falling over the brink and the remaining two concern rock fall deaths. There is one account of suicide but the other stories involve children who are victims of circumstance, or young people enjoying the breathtaking view before inevitable tragedy befalls them. All of Burke's stories invoke the image of innocence before the literal fall.

Before the end of the chapter, Burke provides the section, 'The White Canoes: An Indian Legend'. In his version, the maid is named Lena and her father, who is called Oronta, is a proud Seneca chief. Every autumn his people send a canoe loaded with the summer's harvest over the waterfall, 'to be paddled by the fairest maiden that had just then arrived at woman-hood'. In Burke's tone and language, he conveys the story as an authentic Indian legend and disavows his authority as writer and embellisher of the story. ${ }^{21}$ Few details are offered beyond the circumstances of her death and that she sacrifices herself willingly, but not before her father can join her in his own white canoe, in an act which Burke oddly describes as hopeful:

By a strange chance, Lena's little vessel pauses by a rock, just on the verge of descent-permitting Oronta's to come near-when, both together rise upon the plunging rapids, one look-one mutual look of love, of hope, of happiness, is exchanged-and the forest rings again with the yell of the Senecas, as the father and child drop down the cataract together with their WHITE CANOES!22

Burke ends his morbid tale by likening the Falls to an alter, whose mists resemble incense as Lena and Oronta's spirits cross the rainbow and rise to heaven.

William Trumbull's versed and metered book-length poem, 'The Legend of the White Canoe' (1894), embellishes Burke's story by adding elements of betrayal and the heightened internal conflict of the maid's father, Kwansind. ${ }^{23}$ We are introduced to a community on the brink of destruction: the Seneca 'children of the forest' face 
starvation, are prey to the bloody raids of competing communities and must abide by the whims of cruel and blood-starved gods:

Here the children of the forest, spellbound by that deafening roar, Stopped to gaze with listening wonder, in the simpler days of yore;

Awe-struck, gazing in silent worship, well beseeming Nature's child, As in chase they roamed the plain, or tracked in war the pathless wild:

And as often as they listened, on the voices of the flood

Deep were borne the Spirit's mutterings, calling fierce for human blood;

Ay, and sacrifice more cruel in that cry they understood:

Gift of Nature's choicest treasure, peerless budding womanhood!24 According to the narrator, the Seneca have abandoned their spiritual (or superstitious) obligations to their gods, the result of which is their starvation, pestilence and war.

The maid, who is now called Wenonah, offers the image of placid beauty and ripening sexuality in this chaotic context. Wenonah's ignorance of her influence over men tempers our view of her formidable sexuality. We are presented with the image of a woman on the verge of sexual maturity, who is also utterly innocent:

Fairest of the laughing daughters by blue Seneca's rippling tide,

Was the Indian maid, Wenonah, sturdy Kwansind's joy and pride:

Eyes of laughter, like the sunshine dancing in her native lake,

O'er whose depths, anon, fleet shadows chasing cast their trailing wake;

Lips of tempting ruddy hue like mountain berries gleaming fair;

Raven locks, whose glossy luster shone like dark-stemmed maidenhair;

Whilst rich mantling color tinges an olive cheek, whose crimson flush

Vied with flaming woodland leaves when touched with Autumn's scarlet blush.

And the music of her laughter, when amid the joyous throng,

She, hailed Queen by all maidens, led with merriest quip and song,

Fell in sweetest rippling cadence, sounding thro' the leafy way

Like the purl of hidden brooklet murmuring soft in distant play;

As in freest fancy roving, far removed from cares or strife,

With fresh eager zest exulting in youth's bounding sense of life; 
Bright she moved, a winsome picture, framed by nature's matchless art

In all scenes of joy and beauty royally to bear her part. 25

Having spurned the romantic efforts of the much older medicine man, Wenonah has sealed her fate. The pride-sore, scheming medicine man, taking advantage of the community's now-abandoned practice of human sacrifice, their superstitious fears, and the precarious future which threatens them, meets with the 'warrior's council' to tell them that the spirit of the Niagara river has demanded the sacrifice of a young virgin, lest peace and nature's bounty be denied them forever. Notably the river god is presented to us as a man, and the references to Wenonah as his 'bride' leave us to draw the obvious conclusion that Wenonah's new role is sex object and potential reproductive body for the god. ${ }^{26}$ The warrior council, concerned with the precarious future of their small, vulnerable and slow-to-adapt community see the medicine man's proposal as the most viable option for their security. They determine that Wenonah, the tribe's most beautiful daughter, is the obvious candidate for sacrifice.

Wenonah's father, Kwansind (a raiding tribe has already slaughtered his wife), is the wise chief who can see through the medicine man's lies but is powerless to defy the council. He tells his daughter that she is to die. With the standard stoicism associated with such popular images of Indigenous peoples, Wenonah consents without objection. Her role as tantalising sacrifice to an angry male river god utterly eclipses her internal life, and while she is the reason for the story, she is not its centre. Rather, Kwansind's struggle as leader of a community at the brink of oblivion, rival of a devious medicine man and father to a potential human sacrifice provides the story's substance.

When the fated day arrives, the crowd gathers on the shore, in an orgiastic fit and awaits the arrival (and departure) of Wenonah in her white canoe. Again, Trumbull reminds his readers of the child-like simplicity and eagerness of Wenonah's people to appease their angry gods, even at the cost of human life:

There they danced in wild carousal, thro' that glorious moonlit night,

Love and friendship all forgotten, in their orgie's fierce delight;

Thinking thus, poor simple children, best the dread wrath to assuage

Of that Spirit dark, whose roaring told of boundless, sullen rage. ${ }^{27}$

We are left on the shore to watch with the frantic crowd who will abandon their own to a sullen god, as Wenonah's canoe is taken by the current, she resting dumbly and 
beautifully amid summer flowers and the harvest's bounty. At the last moment, Kwansind submits to his paternal instincts and paddles a canoe out to Wenonah, to join her in death:

Ay; 'twas Kwansind! Love, triumphant over every fear and doubt, Love had won the final victory, putting stubborn pride to rout.

By that one brief glance at meeting, in his tender yearning eyes,

Clear she reads the pregnant meaning of that love-wrought sacrifice:-

Not forgotten, not forsaken, in that lonely, bitter hour!

Then, tho' certain death await her, answering to his love's strong power

Leaps the light of new-born gladness in her eyes!-with quickened breath,

Clasped as one, they pass the portal to the shadowy realm of death. ${ }^{28}$

Trumbull tells us that even now, as Wenonah's spectre pushes off from the shore in her white canoe, she is again joined by the spectre of her father. They embrace again as they slip beyond the brink.

Willard Parker's 'Niagara's Rainbow: The Legend of the White Canoe' (1922) has the maid riding over the brink, but this time with her lover, while her devoted father witnesses helplessly from the shore. ${ }^{29}$ In this version, the river and the god who require the sacrifice are separate: the god is masculine, the river is feminine and both are angry. The scheming medicine man is effaced and Wenonah's lover is a young warrior named Uncas. This time, all are present with the 'wise men' who pronounce Wenona's fate. Her father objects,

'Nay! nay!'

He cries, 'If naught but that our doom can stay,

We'll brave the famine's pestilential breath,

Till all the tribe lies stark and cold in death!'30

Wenonah protests in a speech that is vaguely reminiscent of a Shakespearean heroine's monologue, and that transcends her femininity by condemning it:

Up springs Wenonah: 'Father! hear me speak!

Though but a woman, think me not so weak

That I would shrink, a coward, from flood or fire,

To save my tribe! My blood is thine, my sire!

Lead on, Oh! warriors, to Niagara's Fall

Its might shall not my woman's heart appal! 
Farewell, my sire! Uncas, my love, farewell!

Great Water-god! sound thou Wenonah's knell!

As the headstrong heroine pushes from the shore, Uncas sprints his canoe to join her in a final embrace before the fatal drop. His fellow warriors are horrified, then griefstricken by the loss of the brave. The river seems to share their sentiment and sends up a rainbow in tribute to Uncas:

The spray-drops fall, tinted with the rainbow's hue

'The Spirit weeps,' they cry, 'for Uncas brave-

The Spirit's bow lies upon Uncas' Grave!'

And still the mists from her vexed bosom rise,

Niagara's tears for Love's great sacrifice,

And still o'er Uncas' grave the spirit's rainbow lies. ${ }^{31}$

The rainbow is the river's lament for the loss of Uncas, while Wenonah's death is left oddly and conspicuously un-commemorated.

The Maid of the Mist story has been taken up in many other forms. It has been set to music in Henry Hadley's ballad, 'Lelawala: A Legend of Niagara', which was written for a chorus and opera. ${ }^{32}$ In 1926 Charles Wakefield Cadman published his three-part operetta, 'Lelawala: Or the Maid of Niagara',33 which was greeted with overwhelming approval from audiences and critics. ${ }^{34}$ The period during which Hadley's and Wakefield's musical efforts were published and mounted is known for its stylised and demeaning representations of Indigenous people. The 'Indianist Movement' spanned the 1880s to the 1920s; cultural expression of this era was explicitly racist by today's standards, and drew upon the well-established ideas of noble savagery and Indian degeneracy. Songs and performances arising from these ideas enjoyed wide popularity. Duane M. Matz and Rayna Green offer exhaustive analyses of the Indianist Movement and its influence on musical representations (both Green's and Matz's analyses encompass various popular cultural forms). ${ }^{35}$ Matz explains that Indianist songs were heavily influenced by the wealth of 'coon songs' in North American popular culture. ${ }^{36}$ 'Coon songs' were deeply racist and comedic portrayals of Black people, and these songs were written and performed by and for whites. 'Coon songs' and other parodies and performances of racial alterity are instructive because, as Eric Lott explains in the context of blackface minstrelsy, they demonstrate the white nation's containment and control of racial otherness by 
absorbing and thereby immunising against it. ${ }^{37}$ In other words, the construction, performance and enthusiastic consumption of this difference were critical to the development and defence of whiteness in the settler nation. While 'coon songs' and Indianist cultural production shared the traits of racist humour, the motifs of human sacrifice, ambivalent gods, and unforgiving nature were unique to Indianist cultural production.

Today the Maid of the Mist myth competes with the ephemera, histories and stories of the tourist industry, which crowd the cultural landscape. Visitors both marvel at the cataract and bemoan the very industry that brought them to its shores. Many popular historians have followed suit, slyly winking at their audiences when they call the space a circus or dismiss its myths as lies. ${ }^{38}$ This rhetoric of dismissal justified by the conspicuous production and consumption of the sideshow at Niagara risks also dismissing settler colonial power and decolonial resistance there. The recent response to the racism and sexism of the myth has been to hollow it out, leaving the general moniker the maid of the mist to be filled with the tour boat experience, a stroll through the perpetually crowded Maid of the Mist marketplace, or the novelty of plaster of Paris and buckskin figurines of Indigenous women in canoes. As to the particular violence done to Indigenous knowledge systems and Indigenous women's agency, this new landscape seems to have no room. Bottle openers, novelty cameras, magnets and countless other forms of ephemera depicting the Maid of the Mist steamboats fill countless bins in the city's many souvenir shops. One keychain in particular is symbolic of the relationship between the boat and the myth. It is round and inside is a rotating coin-like insert framed by a ring that reads 'Maid of the Mist-Niagara Falls'. Flipped one way and the words frame an image of the boat. Flipped the other way and those words now frame these:

Named after the legendary Indian Maiden Lelawala, whose spirit is said to reign over Niagara Falls, the popular boat cruises have been thrilling visitors from the world over since 1846. Originally used to ferry passengers across the river, the boat became a tourist attraction in 1848 when a suspension bridge was opened. Since then, millions of visitors including royalty and presidents have experienced the thunder of the Falls and its gentle mist on a succession of boats named 'Maid of the Mist'. 
Until 1996, the steamboat company would treat its patrons to a prerecorded telling of the story as they were ferried into the spray, suggesting that their journey resembled the maid's and lending an air of authenticity which 'Indian maiden' stories afford. When the daytime talk show, 'Live with Regis and Kathie Lee' was scheduled to film on location at Niagara Falls in September 1996, the American Indian Movement (AIM), Nanto (a Native American arts and cultural group) and others planned to stage a public demonstration there to bring attention to their cause against the telling of the myth as though it were historical fact. The Tuscarora, Seneca and surrounding nations never practiced human sacrifice. Further, in all these nations, women are the leaders, diplomats and centre of community life; femicide and its aestheticisation are categorically not Indigenous practices. Tuscarora and Seneca leaders and activists have long disputed the tourist industry's retelling of the Maid of the Mist story, but since the practice had proven lucrative Indigenous resistance to the story had not factored in the business plans of tourist companies before then.

Confronted with the increasingly frequent protests during the summer of 1996, the Maid of the Mist steamboat company stubbornly refused to recognise its hand in perpetuating racism. 'We're portrayed as savages. This has to stop,' said Bill 'Grandpa Bear' Swanson, executive director of AIM's New York chapter. ${ }^{39}$ Allen Jameson, director of Nanto, argued that the company's telling of the myth damaged the esteem and integrity of First Nations and the myth itself was 'racist propaganda'.40 The Maid of the Mist Steamboat Corporation's vice president, Christopher M. Glynn responded: 'To accuse us of racism is outrageous ... And we are not real anxious to change what we've been doing for one hundred years.' ${ }^{41}$ Eventually, the company had little option but to relent. Because of the international attention Regis and Kathie Lee would bring and the attendant threat of receiving bad press, by 5 September 1996 the corporation had backed away from the myth altogether, stating the story was best left to historians and Indigenous people to retell and explain. ${ }^{42}$ The steamboat corporation's president, James Glenn, announced the decision: 'Since the legend is not important to the existing experience we provide our visitors to the Falls, it will no longer be described.' 43 He added that the myth would be stricken from all of the corporation's literature and promotional materials. Today, when tourists ride in any boat in the Maid of the Mist fleet, they 
will hear trivia and historical snippets; they will not hear the Maid of the Mist story. Likewise, the history of the steamboat corporation's and the surrounding community's reliance on the myth, along with the corporation's persistent refusal to abandon it are also rendered invisible.

The corporation's refusal to abandon the myth and its ultimate decision to cleanse its historical records of all reference to the myth under threat of public scrutiny via Live with Regis and Kathie Lee indicates something more than the desire to simply avoid offence. The Niagara Falls tourist industry, like all other tourist sites, relies on favorable public opinion and in this debate the steamboat company had nothing to gain by appearing stubborn and insensitive. Striking the Maid of the Mist myth from the company's records, however, does not 'set the record straight'; it demonstrates the ways that such ideologically laden stories are viscerally connected to the practice of (always incomplete) erasure as they are perpetually called upon and cast away. Called upon to recast Indigenous peoples as stereotypes, to secure the settler's 'rightful' claim to Indigenous land, and cast away when such stories threaten to expose the settler as settler colonist, rather than a people whose claim to Indigenous space is natural and indisputable. In banishing the maid to the fringes of visibility as has ultimately happened as a result of the 1996 dispute, the power and privilege that operate within settler culture slips away from critical discourse and into the normalised mists of settler representational practice.

\section{-THE WOMEN}

The imperative to reclaim Indigenous histories is essential to restoring the centrality of women in Indigenous spiritual and cultural life, which colonial patriarchy has violated. After all, 'the roots of oppression is memory loss' says Laguna, Sioux and Lebanese writer and critic Paula Gunn Allen. ${ }^{44}$ The absence of Indigenous women's agency in settler myths is no accident, it's a culturally engineered erasure, another act of colonialism that directly targets Indigenous women. This discursive vanishment of Indigenous women from stories and histories is 'a silent genocide'. 45 If rendered silent, the centrality of women is likewise silenced and in this silence, women's strength is ignored. Cree and Métis educator Kim Anderson notes that womanhood is the source of power in Indigenous traditions. 
Early newcomers were astonished by the centrality of women to Indigenous life and the absence of violence against women there.46

The sustained colonial attack on Indigenous women, spanning the embodied and representational realms, is an attempt to cut at the heart of Indigenous life in its many social, political, spiritual, cultural and economic dimensions. Lee Maracle explains that women constitute the heart of Indigenous communities, and that patriarchy served colonial ends by imposing and then enforcing a radically different worldview, one where women were subservient to rather than partners with men. ${ }^{47}$ The introduction of colonial patriarchy-patriarchy came on tall ships, it did not travel in canoes-was the first time in Indigenous history that women were marginalised and excluded, their power and knowledge ignored. ${ }^{48}$ Women actively resisted the imposition of patriarchy because they recognised its devastating effects on their cultures, societies and communities, to say nothing of the way that patriarchy threatened women's very lives. ${ }^{49}$ Violence against Indigenous women is a weapon of genocide, which as Andrea Smith (Cherokee) says, destroys Indigenous people's 'sense of being a people'. 50

Settler culture is replete with the intermittent appropriation and silencing of Indigenous women and stories. Stories and their telling are powerful, writes Lenore Keeshig-Thobias, and telling, collecting and modifying (in short, appropriating) these stories without regard for what stories are demonstrates the abuse of power. 'Stories are not just entertainment. Stories are power ... They reflect the deepest, most intimate perceptions, relationships and attitudes of a people. Stories show how a people, a culture thinks. Such wonderful offerings are seldom reproduced by outsiders. ${ }^{51}$ Stories are governed by protocols of telling and listening that respect the power they harness and the relationships between the story, spiritual and animal worlds, teller and listener. The colonial practice of appropriation seeks to vanish the significance of relations in which stories exist, by reducing them to escapist or incidental fancy, or to the raw materials for research in ways that lack accountability to these stories and the people who tell and keep them. ${ }^{52}$ Maori scholar Linda Tuhiwai Smith writes that Indigenous peoples globally have been witness to the erasure of their own stories and histories as they are taken up and distorted by non-Indigenous scholars. ${ }^{53}$ Telling stories and histories demand the 'rewriting and rerighting' of colonial texts; it is a matter of self-determination. ${ }^{54}$ The 
reductive treatment of stories by attempting to rend them from their knowledge systems does violence to them, which is compounded further by the assumption that stories are simply free for the taking, without regard for the relationships between tellers, listeners, the story and the land. 'These are powerful stories, powerful as medicine or tobacco. But, like medicine or tobacco whose smoke is used to carry prayers up to Creator, stories must be used wisely and well or they may be harmful to both tellers and hearers alike.'55 Stories as powerful as medicine or tobacco demand care and the fastidious observation of relations.

Indigenous stories are rooted in knowledge systems, which are in turn rooted in the land. The colonial alienation of Indigenous people from their land, which is intrinsic to their being, carries profound consequences for the sovereignty and wellbeing of Indigenous nations. The stories at Niagara Falls are important because they speak to the sacred connections between land, people, animals and the spirit world. Niagara Falls is a sacred space called Ani-mi-kee' wa-bu, or Thunder Water, and Kichi-ka-be-kong, meaning Great Falls. ${ }^{56}$ It is the Second of Seven Stopping Places in the chi-bi-moo-day-win (or, by Anishinaabe Elder Edward Benton-Banai's translation, migration) of the Anishinaabe when the world was still young and the distinction between spirit and human worlds was fluid. To the Ska ru re, Niagara's waterfall is the place of Mature Flowers or Mature Earth, the woman who fell from the Sky World, touched down and gave birth to a people. ${ }^{57} \mathrm{~A}$ team of waterfowl caught Mature Flowers and guided her to a great turtle, on whose back she walked about, scattering earth that grew into the land she and her children would inhabit. To the Seneca (another member nation of the Haudenosaunee Confederacy) Niagara Falls is a place of Thunder Beings. Darwin John (Seneca) explains:

Thunder Beings were trying to remove a serpent that had been terrorising the area, and during the struggle they threw down the huge snake and that carved out the horseshoe shape of the Canadian Falls. He [the snake] was placed in the underworld, and the route to the underworld was through Devil's Hole State Park. There's a cave there and that's where the snake passed on his way to the underworld. 58

These are stories that tell us not only how to live with other people, but how to live with the animals, the land and spirit worlds. To end the conversation about 
meetings and meaning at Niagara with the tourist traps overlooks Indigenous knowledge and story systems.

Storytelling acknowledges the centrality of Aboriginal knowledges and in colonial space, where this knowledge is often dismissed, storytelling can provide an 'anchor' in the 'ideological and spatial diaspora' to which Indigenous people have been subjected, says Cree artist and scholar Neal McLeod.59 This is no small task. Indigenous knowledge systems are routinely misrepresented and poorly understood. Political philosophers Audra Simpson (citizen of the Kanawake First Nation) and Dale Turner (citizen of the Temagami First Nation) note that Indigenous philosophies have thrived for millennia without the influence of Europeans and that settlers fail to recognise the limits of Eurocentric understanding. 60 The imposition of silence in the form of the non-Indigenous failure to acknowledge and engage with Indigenous political philosophies counts as yet another manifestation of colonisation. Further, Indigenous political philosophies teach that relatedness between people, the land, animals and spirit world, sacredness and tradition are normative principles in which Indigenous political claims are rooted. ${ }^{61}$ This is not easily translatable 'into cultures that unproblematically accept the discourses of rights, sovereignty, and nationhood as the only authoritative source of Indigenous political claims'. Critically important here is the recovery of Indigenous women's histories and stories from the discursive silencing upon which settler culture depends.

\section{-CONCLUSION}

The Maid of the Mist myth is, as I have said, a marker of uneasy resistance in a settler cultural context. This is no nostalgic lament for the 'Indian maiden'. After all, it is a product of settler culture that works to normalise the settler and imperil Indigenous sovereignty. However, the contemporary settler strategy of backing away from the Maid of the Mist myth would suggest that the representation itself is the source of conflict, rather than the privilege enacted in its production and consumption, the power operationalised in its centrality and subsequent marginalisation, and the culture through which it is woven. Conflict that arises from profound and persistent power imbalances does not vanish when the maid is pushed from the centre of settler culture to its margins. 
Today, the Maid of the Mist is a shadowy presence on the settler cultural landscape; a general form utterly lacking specificity (the name could reference the tour boat, the marketplace, the Indian maiden, individually or in concert, for example). The interchangeability of meaning here is an effect of colonial culture, where the image of the Indigenous woman is invoked to justify the colonial imperative, to represent the landscape, or to channel imperial sexual anxieties, thus using the image of the Indigenous woman without actually representing her. It was a shadowy presence lacking specificity until 1996, when the myth was made concrete, localised on the deck of the tour boat in the mist. Indigenous activists, I hasten to add, did not concretise the myth; they identified it as a settler colonial representational practice, a process of delegitimising Indigenous sovereignty. The steamboat corporation's ultimate decision to discard the myth, thus suggesting that it was the telling of the myth that produced the activists' grievance, secured the myth's shadowy presence by sacrificing this specific instantiation.

Reclaiming stories that tell of the central importance of Indigenous women to Indigenous cultural, political and cosmological life makes the 'silent genocide' audible. The settler cultural representation of the Indian maiden in the water can instantiate the telling of Indigenous stories, for example, the story of Mature Flowers who accomplishes two tasks that no man can: she travels between plains of existence without dying, and she gives birth to the first peoples of this land. Niagara Falls is an ancient landscape and settler culture along with its accompanying patriarchal ideologies are recent, albeit powerful and entrenched, additions. In this space, the subaltern status of Indigenous women is not a historical constant; this subaltern was not always subaltern. Retelling the histories of Indigenous resistance to settler cultural politics and its attempted displacement of Indigenous epistemological and embodied belonging at Niagara Falls exposes the constructedness of settler culture and creates productive and risky spaces of decolonial resistance. 
Robinder Kaur Sehdev holds a PhD in Communication and Culture from York and Ryerson Universities (Canada) where she researched the participation of popular cultural representational practices in the normalization of the myth of the innocent settler state. Her current research asks how the concept of sovereignty is conceptualized and taken up by anti-racist feminists seeking solidarity with Indigenous peoples in Canada. This research queries the possibilities of developing social justice, specifically feminist, alliances across colonial differences. Her work can be found in the Australian Critical Race and Whiteness Studies Journal, the Canadian Journal of Law and Society, as well as a number of anthologies on race and settler studies.

\section{-NOTES}

1 Sherene H. Razack, 'When Space Becomes Race' in Race, Space, and the Law: Unmapping a White Settler Society, ed. Sherene H. Razack, Between the Lines, Toronto, 2002, p. 1.

2 Razack, p. 2

3 Janice Acoose, Iskwewak-Kah' Ki Yaw Ni: Neither Indian Princesses nor Easy Squaws, Women's Press, Toronto, 1995; Philip Bellfy, 'Permission and Possession: The Identity Tightrope' in Walking a Tightrope: Aboriginal People and Their Representations, ed. Ute Lischke and David T. McNab, Wilfrid Laurier University Press, Waterloo, 2005; Beth Brant, 'Grandmothers of a New World' in Through Indian Eyes: The Native Experience in Books for Children, ed. Beverly Slapin and Doris Seale, New Society Publishers, Philadephia, PA; Gabriola Island, BC, 1987, pp. 102-13; Philip Deloria, Playing Indian, Yale University Press, New Haven, 1998; Rayna Green, 'The Tribe Called Wannabee: Playing Indian in America and Europe', Folklore, vol. 99, 1994, pp. 33-55; Emma LaRocque, 'Tides, Towns and Trains', in Joan Turner (ed.), Living the Changes, University of Manitoba Press, Winnipeg, 1990, pp. 76-90.

4 Terry Goldie, Fear and Temptation: The Image of the Indigene in Canadian, Australian, and New Zealand Literatures, McGill-Queen's University Press, Kingston and Montreal, 1989, pp. 86, 61.

5 Goldie, pp. 84-6.

${ }^{6}$ M. Elsie Marubbio, Killing the Indian Maiden: Images of Native American Women in Film, University of Kentucky, Lexingon, KY, 2006.

7 Goldie; Marubbio.

8 Karen Dubinksy, The Second Greatest Disappointment: Honeymooning and Tourism at Niagara Falls, Between the Lines, Toronto, 1999, p. 68.

${ }^{9}$ Anne McClintock, Imperial Leather: Race, Gender, and Sexuality in the Colonial World, Routledge, New York, 1995. 
${ }^{10}$ Spivak investigates the colonial practice of representing indigenous women as victims of their cultures and communities (specifically, indigenous men) in her work on Hindu women's voice and agency in the context of British imperial representations of Sati (widow burning) in India. Spivak poses two statements meant to encapsulate the dominant discourses surrounding the practice, both of which, while invoking the image of the burning bride, silence her: 'white men are saving brown women from brown men' (p. 92) and 'the women actually wanted to die' (p. 93). The first sentence communicates the justification for British imperialism rooted in the discourse of the white man as saviour of brown women. At the heart of such a statement is the notion that imperialism is the mechanism by which the 'good society' (p. 94) can be achieved. The marker of the so-called good society is 'the espousal of women as object of protection from her own kind' (ibid.). The second sentence, 'the women actually wanted to die' is 'the Indian nativist argument, a parody of the nostalgia for lost origins' (p. 93), which claims that widows exercised their freedom by consenting to the practice of widow sacrifice. According to such logic, any attempt to prevent widows from self-immolation amounts to the erosion of their freedom to choose death. While both statements call upon women and invoke their freedoms, women's voice is rendered silent and agency invisible. The task of the postcolonial intellectual, says Spivak, is to render such ideological formations the object of analysis by articulating them as ideological formations and 'measuring silences' (p. 92) they produce. As the rights of women of colour are routinely opportunistically invoked at the expense of the voice of women of colour, Spivak's method of naming and deconstructing colonial knowledge production remains relevant and crucial today. Gayatri Chakravorty Spivak, 'Can the Subaltern Speak?' in Colonial Discourse and Post-Colonial Theory: A Reader, ed. Patrick Williams and Laura Chrisman, Columbia University Press, New York, 1994, pp. 66111.

11 Brant.

12 Ibid., p. 102.

13 Ibid., p. 103.

14 Jolene Rickard, 'Cew Ete Haw I Tih: The Bird that Carries Language Back to Another' in Partial Recall: Photographs of Native North America, ed. Lucy R. Lippard, The New Press, New York 1992, pp. 105111. p. 109.

15 The Tuscarora have a reserve on the US side of the border at Niagara Falls and so were subject to US Indian policies.

${ }^{16}$ See Niagara: A History of the Falls [film], prod. and dir. Rachel Low, History Channel, New York, 2002.

17 In the 1720s the Tuscarora Nation was pushed from their homeland in what is now called the Carolinas. Fleeing northward, the nation appealed to the Haudenosaunee Confederacy. The Seneca (a member nation of the confederacy) permitted them to settle in the Niagara Region and the Tuscarora were adopted as 'little brothers,' thus expanding the confederacy from five to six nations. As a result of this expansion, it is commonly called the Six Nations Confederacy.

${ }^{18}$ Rickard, p. 109. 
${ }^{19}$ I understand 'decolonial agency' to be both adaptive strategies of resistance to colonisation as well as the recursive articulation and adaptation of indigenous ways of knowing and doing. This enacts what Ngugi wa Thiong'o calls 'the decolonisation of the mind' by reconnecting identification and environment, knowledge and lived experience, while colonial alienation would seek to disaggregate, 'producing a society of bodiless heads and headless bodies' (p. 28). A bodiless head cannot act; a headless body cannot think. Decolonial agency involves both acting and thinking, both resisting colonisation and enacting indigenous ways of knowing and doing. This is a reunion of head and body that knows its origins. Tuscarora women's labour amounted to more than the exchange of goods for the respite of their nation. Theirs was an attempt to reestablish connections between history and lived experience, all while enacting their agency as Tuscarora women, and the continued survivance (see Visenor) of their nation. Ngugi wa Thiong'o, Decolonising the Mind: The Politics of Language in African Literature, J. Currey; Heinemann: London; Portsmouth, New Hampshire, 1986; Gerald Vizenor, Manifest Manners: Narratives on Postindian Survivance, University of Nebraska Press: Lincold, Nebraska, 1999.

${ }^{20}$ Andrew Burke, Burke's Descriptive Guide; or, The Visitor's Companion to Niagara Falls: Its Strange and Wonderful Localities, Andrew Burke, Buffalo, 1851.

21 The notion of authenticity is wielded as a weapon and is often aimed at the bodies of Aboriginal women: settler 'Indian' policies in what we currently call Canada policed 'Indian' identity through the creation and enforcement of 'Indian status' which disregarded the centrality of women by declaring male lineage as the grounds for recognition, thereby undermining the sovereignty of Indigenous nations and the centrality of women within it. To be 'authentically Indian' one had to demonstrate status through the male line. Kim Anderson and Bonita Lawrence offer analyses of the impact of Indian status on Aboriginal peoples. Anderson's analysis of Native womanhood confronts the Indian act and the patriarchal, racist displacement of Aboriginal women from the centre to the periphery. Andrea Smith argues that these policies, as well as the settler cultural construction of Aboriginal women as 'inherently rapable' enables sexualised violence against Aboriginal women. Kim Anderson, $A$ Recognition of Being: Reconstructing Native Womanhood, Sumach Press, Toronto, 2000; Bonita Lawrence, 'Real' Indians and Others: Mixed-Blood Urban Native Peoples and Indigenous Nationhood, University of British Columbia Press, Vancouver, 2004; Bonita Lawrence, 'Gender, Race, and the Recognition of Native Identity in Canada and the United States: An Overview', Hypatia, vol. 8, no. 2, 2003, pp. 3-31; Andrea Smith, Conquest: Sexual Violence and American Indian Genocide, South End Press, Cambridge, Massachusettes, 2005, p. 3.

22 Burke, p. 104.

23 William Trumbull, The Legend of the White Canoe, G.P. Putnam \& Sons, New York \& London, 1894.

24 Ibid., p. 3.

25 Ibid., pp. 5, 7. 
${ }^{26}$ Lini Grol's children's story presents a tamer version of Trumbull's virgin-temptress: she is 'too good for any man, meant for a god'. Lini Groll, Lelawala: A Legend of the Maid of the Mist, the Heroine from the Niagara Peninsula, Foothill Studio, Foothill, Ontario, 1971, p. 17.

27 Trumbull, p. 43.

28 Ibid., p. 51.

${ }^{29}$ Willard Parker, Niagara's Rainbow: The Legend of the White Canoe, Conshohocken, Pennsylvania, 1922.

30 Parker, stanza v.

31 Parker, stanza xii.

32 Henry Hadley, Lelawala: A Legend of Niagara, Arthur Schmidt, Boston, 1898.

${ }^{33}$ Charles Wakefield Cadman, Lelawala: Or the Maid of Niagara, A Dramatic Operetta in Three Acts for Mixed Chorus, Willis Music, Cincinnati, 1926.

34 See Will Earhart, “Lelawala, The Maid of Niagara” by Charles Wakefield Cadman: Review', Music Supervisor's Journal, vol. 13, no. 5, 1927, p. 73.

35 Rayna Green, 'The Tribe Called Wannabee', pp. 33-55; Duane M. Matz, 'Images of Indians in American Popular Culture since 1865', PhD thesis, Illinois State University, 1988.

36 Matz, p. 245.

37 Eric Lott, Love and Theft: Blackface Minstrelsy and the American Working Class, Oxford University Press, New York, 1993.

${ }^{38}$ For examples, see Ginger Strand, Inventing Niagara: Beauty, Power, and Lies, Simon \& Schuster, New York, 2008; Pierre Berton, Niagara: A History of the Falls, McClelland \& Stewart, Toronto, 1992; Gordon Donaldson, Niagara! The Eternal Circus, Doubleday, Toronto, 1979.

39 Phil Fairbanks, 'Native Americans Ask Tours to Drop Dubious Tale', Buffalo News, 1 September 1996, p. B4.

40 Ibid.

41 Ibid.

42 Stephens, 'Maid of the Mist Corp. Will Stop Telling Tale', Niagara Gazette, 5 September 1996, p. 1.

${ }^{43}$ Ricciuto, 'Maid of the Mist Drops "Racist" Legend from Tourist Spiel', Niagara Falls Review, 5 September 1996, p. 1.

44 Paula Gunn Allen, The Sacred Hoop: Recovering the Feminine in American Indian Traditions, Beacon Press, Boston, 1992, p. 213.

45 Brant, p. 112

46 Anderson, p. 95; see also Patricia Monture-Angus, Thunder in my Soul: A Mohawk Woman Speaks, Fernwood, Halifax, 1995; Joyce Green, 'Taking Account of Aboriginal Feminism' in Making Space for Indigenous Feminism, ed. Joyce Green, Fernwood Publishing, Zed Books, Blackpoint, London, 2007, pp. $20-32$. 
${ }^{47}$ Lee Maracle, I Am Woman: A Native Perspective on Sociology and Feminism, Press Gang, Vancouver, 1996, pp. 62-70; 'Racism, Sexism and Patriarchy' in Returning the Gaze: Essays on Racism, Feminism and Politics, ed. Himani Bannerji, Sister Vision, Toronto, 1993, pp. 148-58.

${ }^{48}$ Anderson, p. 70.

49 Winona Stevenson, 'Colonialism and First Nations Women in Canada' in Scratching the Surface: Canadian Anti-racist Feminist Thought, ed. Enakshi Dua and Andrea Robertson Women's Press, Toronto, pp. 49-80.

50 Smith, p. 3.

${ }^{51}$ Lenore Keeshig-Thobias, 'Not Just Entertainment' in Through Indian Eyes: The Native Experience in Books for Children, ed. Beverly Slapin and Doris Seale, New Society Publishers, Philadephia, PA; Gabriola Island, BC, 1987, pp. 98-101.

52 Thomas King's The Truth About Stories, in particular the chapter, 'Let Me Entertain You' explains that Aboriginal stories, deemed 'entertainment' in non-Aboriginal contexts, implies that they are unnecessary, non-educative flourishes which accompany non-Aboriginal discourse. Thomas King, The Truth About Stories: A Native Narrative, House of Anansi Press, Toronto, 2003.

53 Linda Tuhiwai Smith, Decolonizing Methodologies: Research and Indigenous Peoples, Zed Books; University of Otago Press, London and New York, Dunedin, 1999, pp. 29, 33.

54 Smith, p. 28.

55 Joseph Burchac, 'Storytelling and the Sacred: On the Uses of Native American Stories' in Through Indian Eyes: The Native Experience in Books for Children, ed. Beverly Slapin and Doris Seale, New Society Publishers, Philadephia, Gabriola Island, 1987, pp. 91-7.

56 Edward Benton-Benai, The Mishomis Book: The Voice of the Ojibway, Red School House, Saint Paul, Minnesota, 1988.

57 Jolene Richard, 'Cew Ete Haw I Tih: The Bird that Carries Language Back to Another' in Partial Recall: Photographs of Native North Americans, ed. Lucy R. Lippard, The New Press, New York, 1992, p. 105. 58 John quoted in Ginger Strand, Inventing Niagara: Beauty, Power, and Lies, Simon \& Schuster, New York, 2008, pp. 16-7.

${ }^{59}$ Neal McLeod, 'Coming Home Through Stories' in (Ad)dressing Our Words: Aboriginal Perspectives on Aboriginal Literatures, ed. Arnold Garnet Ruffo, Theytus Books, Penticton, 2001, pp. 17-36.

60 Dale Turner and Audre Simpson, Indigenous Leadership in a Flat World, National Centre for First Nations Governance, Ottawa, 2008.

61 Turner and Simpson, p. 14. 